\section{Plant Population Affects Pumpkin Yield Components}

\author{
Kent E. Cushman ${ }^{1}$, David H. \\ Nagel $^{2}$, Thomas E. Horgan ${ }^{1}$, \\ and Patrick D. Gerard ${ }^{3}$
}

AdDitional INDEX wORDs. Cucurbita sp., plant spacing, planting density, yield

Summary. Pumpkins (Cucurbita pepo,

C. moshata) were grown in northern

Mississippi during 2000 and 2001

for the purpose of more narrowly defining plant population recommendations for commercial production in the humid southeastern United States. Four plant populations were examined for 'Aspen': 908, 1361, 2045, and 3068 plants/acre $(2244,3363,5053$,

${ }^{1}$ North Mississippi Research and Extension Center, P.O Box 1690, Verona, MS 38879. E-mail: kcushman@ ra.msstate.edu.

${ }^{2}$ Dept. of Plant and Soil Sciences, Mississippi State University, Box 9555, Mississippi State, MS 39762. E-mail: dnagel@pss.msstate.edu.

${ }^{3}$ Experimental Statistics Unit, Mississippi State Univer sity, Box 9653, Mississippi State, MS 39762. E-mail: pdgl@ra.msstate.edu

This research supported in part by U.S. Department of Agriculture, Cooperative State Research, Education, and Extension Service Hatch project MIS-149070. Approved for publication as Journal Article No. J10403 of the Mississippi Agricultural and Forestry Experiment Station, Mississippi State University. Mention of a trademark, proprietary product, or vendor does not constitute a guarantee of warranty of the product by Mississippi State University and does not imply its approval to the exclusion of other products or vendors that also may be suitable. We appreciate seed donations from Rupp Seeds Inc. and Harris Seeds. and 7581 plants/ha, respectively) and for 'Howden Biggie': 605, 908, 1361, and 2045 plants/acre $(1495,2244$, 3363,5053 plants/ha, respectively). Plant populations were adjusted by varying in-row spacing while holding between-row spacing constant at $8 \mathrm{ft}(2.4 \mathrm{~m})$. Plant population significantly affected yield of 'Aspen' and 'Howden Biggie'. Linear and quadratic terms were significant for 'Aspen', with maximum yield (ton/ acre and fruit/acre) for the quadratic relationship occurring at about 2045 plants/acre. In contrast, yield of 'Howden Biggie' decreased significantly (ton/acre) and nonsignificantly (fruit/acre) in a linear relationship as plant population increased from 605 to 2045 plants/acre. Plant population significantly affected fruit weight and size. As plant population increased, weight and size decreased slightly but significantly in a linear relationship for 'Aspen' (lb/fruit and inch 3 /fruit) and 'Howden Biggie' (lb/fruit). The quadratic relationship for 'Howden Biggie' (inch ${ }^{3} /$ fruit) was significant and the minimum value occurred at about 1361 plants/acre. Plant population significantly affected pumpkin yield components associated with plant productivity. As plant population increased, number and weight of fruit per plant decreased sharply in a quadratic relationship for 'Aspen' (lb/ plant and fruit/plant) and 'Howden Biggie' (lb/plant). The linear relationship for 'Howden Biggie' (fruit/ plant) also decreased significantly. At the highest plant populations for 'Howden Biggie', $40 \%$ of the plants did not produce marketable pumpkins. In conclusion, recommendations of optimum plant populations for a semi-vining cultivar such as 'Aspen' should be centered on about 2045 plants/acre. Published recommendations from Kentucky appear sound, advocating plant populations within the range of 1360 to 2720 plants/ acre (3361 to 6721 plants/ha). For a vining cultivar such as 'Howden Biggie', recommendations can be as low as 605 plants/acre. Published recommendations from Kentucky and Georgia, along with those published in the Vegetable Crop Guidelines for the Southeastern U.S., advocate plant populations for vining cultivars of approximately 725 to 1465 plants/acre (1790-3620 plants/ha). Our results with 'Howden Biggie', a cultivar that produces larger pumpkins than most other vining cultivars grown for the wholesale market, indicate that producers of vining cultivars should use plant populations from the lowest values of these recommendations or use even lower values. Our results also indicate that growers can control size and weight of pumpkins by varying plant population, with increasing populations resulting in a slight decrease of size and weight.

$\mathrm{R}$ ecommended plant populations for commercial pumpkin production vary widely depending on the source of the recommendation. Each state has its own recommendation and even adjacent states have differences between the highest and lowest values within their range of recommended plant populations (Table 1). Some recommendations are general in nature and are meant to assist with the planting of all pumpkin types, from bush to semi-vining to large-sized vines. Plant populations of these recommendations vary as much

Table 1. Selected plant population recommendations and plant spacings for commercial pumplin production in the United States.

\begin{tabular}{|c|c|c|c|c|c|c|}
\hline \multirow[b]{3}{*}{$\underline{\text { State }}$} & \multicolumn{3}{|c|}{ Vining types } & \multicolumn{3}{|c|}{ Semi-vining types } \\
\hline & \multirow{2}{*}{$\begin{array}{c}\text { Plant } \\
\text { population }\end{array}$} & \multicolumn{2}{|c|}{ Plant spacing } & \multirow{2}{*}{$\begin{array}{c}\text { Plant } \\
\text { population }\end{array}$} & \multicolumn{2}{|c|}{ Plant spacing } \\
\hline & & Between row & Within row & & Between row & Within row \\
\hline & $(\text { plants } / \text { acre })^{\mathrm{z}}$ & -------- $(\mathrm{ft}$ & ------- & (plants/acre) & $-\cdots-\cdots(f t$ & )------ \\
\hline Alabama $^{y}$ & $1090-2420$ & $6-8$ & $3-5$ & $2905-7260$ & $3-5$ & $2-3$ \\
\hline California $^{x}$ & $870-2420$ & $6-10$ & $3-5$ & & & \\
\hline Florida $^{w}$ & $970-2905^{\mathrm{r}}$ & $5-9$ & $3-5$ & & & \\
\hline Georgiav $^{v}$ & $910-1360$ & $8-12$ & 4 & $1360-2040$ & 8 & $2.7-4$ \\
\hline Kentucky ${ }^{u}$ & $725-1465$ & $9-12$ & $3.3-5$ & $1360-2720$ & 8 & $2-4$ \\
\hline New Mexico ${ }^{t}$ & $605-4355$ & $5-12$ & $2-6$ & & & \\
\hline Rupp Seed, Inc. ${ }^{\mathrm{s}}$ & $1210-1450$ & $7.5-9$ & 4 & $1450-1815$ & $6-7.5$ & 4 \\
\hline \multicolumn{7}{|l|}{ Vegetable Crop } \\
\hline Guidelines $^{\mathrm{r}}$ & $870-1360$ & $8-10$ & $4-5$ & $1360-3630$ & $6-8$ & $2-4$ \\
\hline
\end{tabular}


as $700 \%$ from the lowest to highest values. Other recommendations are more specific and are meant for semi-vining (restricted-growth or medium-sized vines) or vining (vigorous or largesized vines) types of pumpkins. Plant populations of these recommendations range $100 \%$ or more from the lowest to highest values within the recommended range. These wide ranges of generally accepted plant populations are not surprising considering the diversity of pumpkin genotypes in cultivation, the differences in cultural practices in use by producers, and the different climates in which the crop is grown.

In the northeastern United States, Reiners and Riggs (1997) reported a significantly linear increase in the number of fruit per acre of 'Wizard', a semi-vining cultivar, and 'Howden', a large-vine cultivar, as plant population increased from 1874 to 7495 plants/ acre (4630 to 18,520 plants/ha). Increasing plant population resulted in increasing yield (by weight) at one location but not the other. Though not a part of the study, it was thought the yield increase at the one location was a result of supplemental irrigation. Increasing plant population resulted in a significantly linear decrease in average fruit size at each location. Reiners and Riggs (1999) reported in a similar study a significantly linear increase in yield of 'Wizard' and 'Howden' as plant population increased from 1210 to 3626 plants/acre (2990-8960 plants/ha). Increasing plant population resulted in increased number of fruit per acre and decreased average fruit size. Increased number of fruit more than compensated for decreasing fruit weight and resulted in an overall increase in yield. In a similar study with watermelon (Citrullus lanatus), it was concluded that the yield component contributing most to increased yields was increased fruit count per unit land area (NeSmith, 1993).Watermelon is another vine crop where recommended plant populations vary widely depending on the state or source of the recommendation. Texas recommends a plant population for commercial triploid watermelon production of 2180 to 3350 plants/acre (5387-8278 plants/ha) (Daniello, 1996), whereas Florida recommends about 1450 to 1740 plants/acre ( 3583 to 4299 plants /ha). A study of the effect of planting density on watermelon fruit size and yield suggested that a plant population of approximately 4030 plants/acre (9958 plants/ha) or lower was optimum for producing fruit of adequate size and yield (Sanders et al., 1999). Motsenbocker and Arancibia (2002) reported that in-row spacing affected the number of triploid melons produced in the small- and extra small-size categories but not in the medium- and large-size categories. The number of small- and extra smallsized melons increased significantly as in-row spacing decreased from 8 to 2 $\mathrm{ft}(2.4-0.6 \mathrm{~m})$. This was equivalent to an increase in plant population from 680 to 2719 plants/acre (1680-6719 plants/ha). The authors concluded, in part, that direct-market growers would benefit from high-density plantings by increasing yield of small-sized melons.

Researchers studying cantaloupe (Cucumis melo) reported that plant population significantly affected yield components (Kultur et al., 2001). As plant population doubled from 14,691 to 29,381 plants/acre $(36,300-$ 72,600 plants/ha), yield in tons per acre increased $69 \%$, number of fruit per acre increased $66 \%$, average fruit weight decreased $10 \%$, number of fruit per plant decreased $24 \%$, and weight of fruit per plant decreased $31 \%$. Though the results of the study were averaged over three genotypes and other factors were examined, these results are typical of the effects of plant population on yield components of most vegetable crops (Wien, 1997). As plant population increases, increases in the number of fruit per acre is normally more than enough to offset decreases in average fruit weight. The overall result is increased yield. Plant productivity, measured on an individual plant basis as number or pounds of fruit per plant, decreases sharply as plant population increases.

Plant population studies are conducted by varying in-row spacing and/or between-row spacing. Reiners and Riggs' first study (1997) controlled plant population by varying in-row spacing while holding between-row spacing constant at $6 \mathrm{ft}(1.8 \mathrm{~m})$. Their second study (Reiners and Riggs, 1999) controlled plant population by varying in-row and between-row spacing. The author's concluded from the second study that yield was slightly increased when pumpkins were planted using wide in-row spacings in combination with narrow between-row spacings, thus making a somewhat square pattern of plants in the field. The authors concluded that this arrangement reduced plant-to-plant competition.

The purpose of this research was to determine whether the wide range of plant populations recommended throughout the United States for commercial pumpkin production could be more narrowly defined, especially for the warm, humid climate of southeastern United States. Results of this research were expected to lead to recommendations of optimum plant stands for pumpkin cultivars that produce medium- and large-sized vines. Results were also expected to lead to an understanding of the effect of plant population on selected yield components.

\section{Materials and methods}

Pumpkin cultivars Aspen and Howden Biggie were planted at the Horticulture Research and Education Unit in Verona, in northern Mississippi, during 2000 and 2001. Four plant populations were examined for 'Aspen': 908, 1361, 2045, and 3068 plants/acre. These populations are equivalent to planting densities of $48.0,32.0,21.3$, and $14.2 \mathrm{ft}^{2} /$ plant, respectively $(4.46,2.97,1.98$, and 1.32 $\mathrm{m}^{2} /$ plant. Four plant populations were also examined for 'Howden Biggie': 605, 908, 1361, and 2045 plants/ acre. These populations are equivalent to planting densities of $72.0,48.0$, 32.0 , and $21.3 \mathrm{ft}^{2} /$ plant, respectively $\left(6.69,4.46,2.97\right.$, and $1.98 \mathrm{~m}^{2} /$ plant $)$. 'Howden Biggie' produces a larger, more vigorous plant than 'Aspen' and planting densities were adjusted to account for this difference.

The soil at Verona is a Quitman fine sandy loam (fine-loamy, siliceous, thermic, Aquic Paleudult). Preplant fertilizer $(7.6 \mathrm{~N}-7.0 \mathrm{P}-21.0 \mathrm{~K})$ was applied before bed making at a rate of $785 \mathrm{lb} /$ acre $\left(879.2 \mathrm{~kg} \cdot \mathrm{ha}^{-1}\right)$ each year according to soil test recommendations. Pumpkins were not grown in the same location each year, but the sites were used for other agricultural crops in previous years. Plant beds were made $0.5 \mathrm{ft}(0.15 \mathrm{~m})$ high and $2.5 \mathrm{ft}$ $(0.76 \mathrm{~m})$ across the top with a presspan-type bed shaper. Beds were spaced $8 \mathrm{ft}(2.4 \mathrm{~m})$ apart, center-to-center, with a 20 -ft- $(6.1 \mathrm{~m})$ wide drive row located between each set of three rows in 2000 and each set of four rows in 2001. Water or fertilizer solution was 


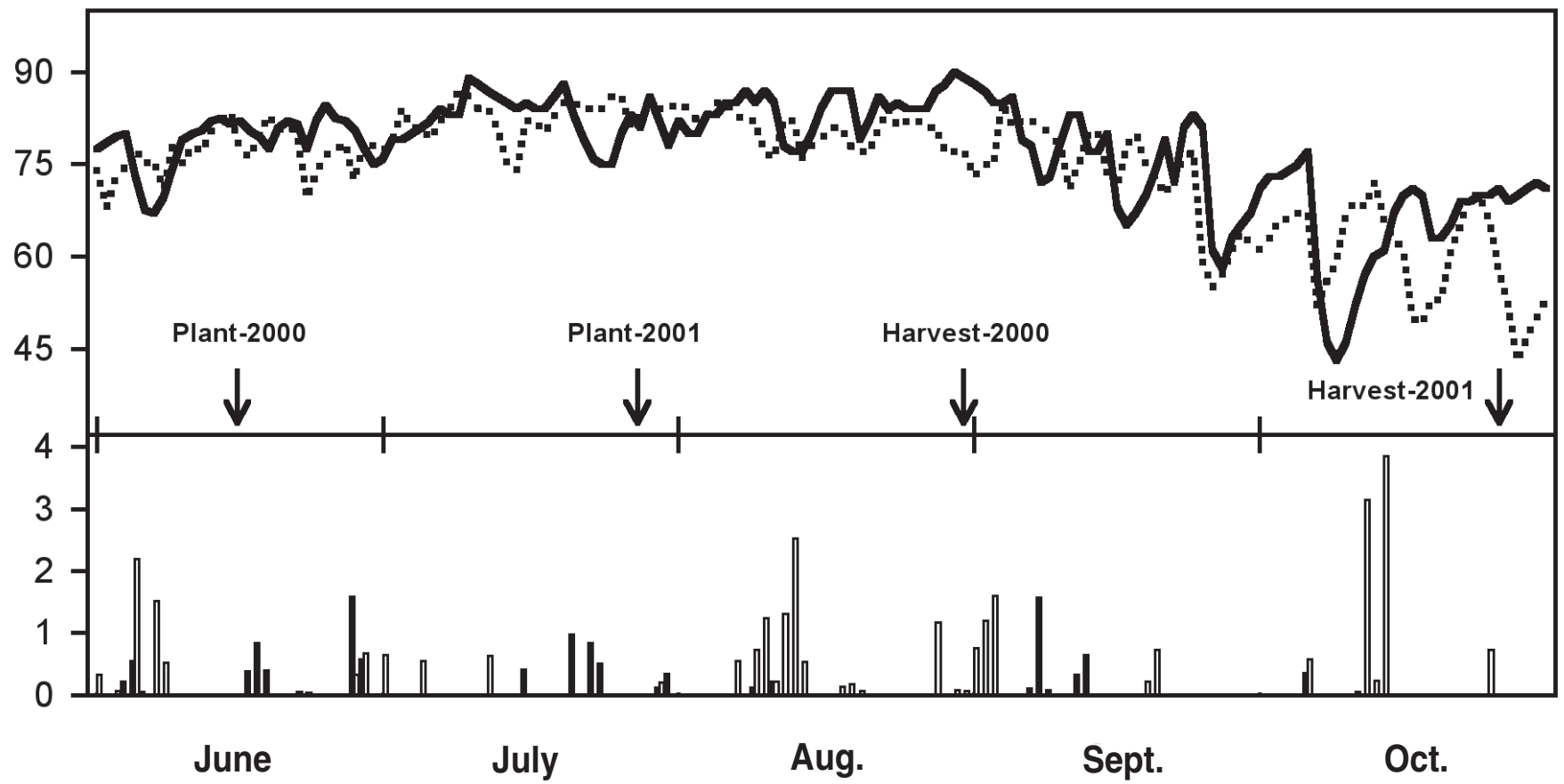

Fig. 1. Average daily air temperature and total daily precipitation at the Horticulture Research and Education Unit in Verona, Miss. Temperatures during the 2000 (solid) and 2001 (dotted) growing seasons. Precipitation during the 2000 (filled) and 2001 (open) growing seasons. Arrows indicate planting and harvest times for each year. ${ }^{\circ} \mathrm{F}=1.8\left({ }^{\circ} \mathrm{C}\right)+32 ; 1$ inch $=25.4 \mathrm{~mm})$.

applied through drip tubing to supply at least $4.7 \mathrm{gal} / \mathrm{ft}\left(58.37 \mathrm{~L} \cdot \mathrm{m}^{-1}\right)$ weekly when plants were large and weather was sunny and warm. Soluble fertilizer was applied once by injecting a concentrated solution of ammonium nitrate $\left(\mathrm{NH}_{4} \mathrm{NO}_{3}\right)$ at about $35 \mathrm{~d}$ after seeding. This supplied an additional $50 \mathrm{lb} /$ acre $\left(56.0 \mathrm{~kg} \cdot \mathrm{ha}^{-1}\right) \mathrm{N}$.

Pumpkins were direct seeded by hand 14 June 2000 and 27 July 2001. Each hill was planted with two or three seeds and then thinned by hand to one plant per hill 2 weeks after emergence. At this time, a few missing plants were replanted with greenhouse-grown seedlings. This resulted in an excellent plant stand for each cultivar and each year. Clomazone herbicide was applied at label rates immediately after seeding. Within 1 week of application, 0.5 to 1.0 inch $(1.27-2.54 \mathrm{~cm})$ of precipitation effectively incorporated the herbicide. Effects of the herbicide became evident in 2000 on many young plants, which exhibited white, bleached leaves. All plants, however, soon recovered and produced green and healthy foliage. Row middles were mechanically cultivated by hand or with a tractor-mounted rototiller 1 month after planting. Esfenvalerate, permethrin, or endosulfan were mixed with chlorothalonil or azoxystrobin and applied on a 7 - to $10-\mathrm{d}$ schedule for insect and disease control. Pest control protectants were alternated every other week. Two to four active beehives per acre (4.9-9.9/ ha) were used each year.

The experimental design was a randomized complete block with four blocks. Cultivar was not part of the experimental design; therefore, 'Aspen' and 'Howden Biggie' were planted in separate plantings each year. In 2000 , each experimental unit (plot) consisted of groups of three rows and an area of $200 \mathrm{ft}^{2}(10 \times 20 \mathrm{ft})\left[18.6 \mathrm{~m}^{2}(3.0 \times 6.1\right.$ $\mathrm{m})]$ was harvested from the center of each plot. In 2001, each experimental unit consisted of groups of four rows and an area of $400 \mathrm{ft}^{2}(20 \times 20 \mathrm{ft})[37.2$ $\left.\mathrm{m}^{2}(6.1 \times 6.1 \mathrm{~m})\right]$ was harvested from the center of each plot.

'Aspen' was harvested 30 Aug. 2000 and 18 Oct. 2001. 'Howden Biggie' was harvested 7 Sept. 2000 and 25 Oct. 2001. Each pumpkin was weighed and measured for height and width. Only pumpkins greater than 5 $\mathrm{lb}(2.3 \mathrm{~kg})$ were considered marketable and included in the statistical analyses. Volume of each pumpkin was calculated as a cylinder: $\left(h t^{*} \pi^{*} r^{2}\right)$. Regression analysis was performed with SAS (SAS Institute, Cary, N.C.). The MIXED procedure was used to analyze data. The effect of year was designated a random effect.

\section{Results and discussion}

Weather conditions were unusually hot and cloud-free in Aug. 2000 and pumpkins matured in $77 \mathrm{~d}$ for 'Aspen' and $85 \mathrm{~d}$ for 'Howden Biggie'. Weather conditions were average in 2001 and pumpkins matured in 85 $\mathrm{d}$ for 'Aspen' and $93 \mathrm{~d}$ for 'Howden Biggie' (Fig l).

Plant population significantly affected yield of 'Aspen' and 'Howden Biggie' (Fig. 2). Linear and quadratic relationships were significant for 'Aspen', with maximum yield (ton/acre and fruit/acre) for the quadratic relationship occurring at about 2045 plants/acre. Plant population affected yield of 'Howden Biggie' differently than 'Aspen'. As plant population increased from 605 to 2045 plants/ acre, yield in ton/acre decreased significantly in a linear relationship. The trend for yield in fruit/acre decreased in a similar and linear manner but at a significance of $P=0.0972$. Our results are not consistent with that of Reiners and Riggs $(1997,1999)$ where increasing plant population of semi-vining and vining cultivars either did not affect yield or increased it in a linear fashion. Our methods differed slightly from theirs in that plant populations in our experiments were adjusted by varying in-row spacing while holding between- 


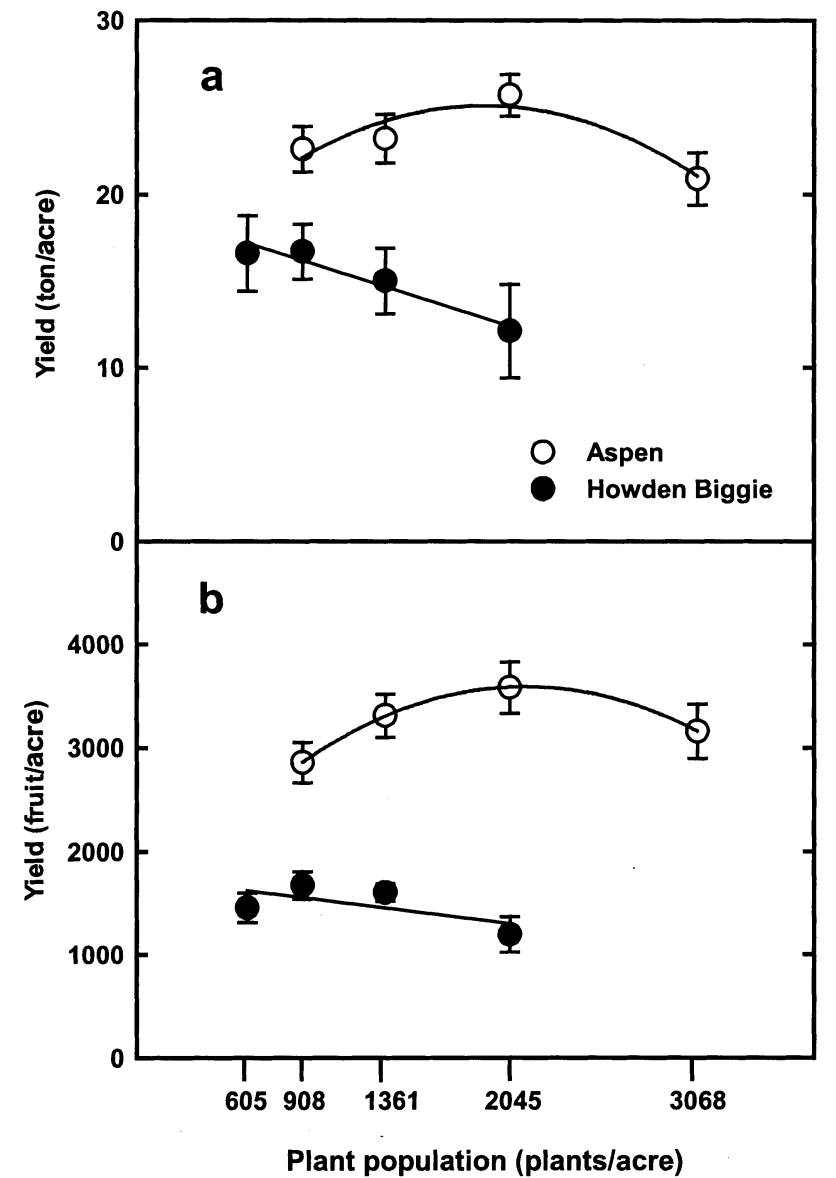

Fig. 2. Yield of pumpkin cultivars Aspen and Howden Biggie grown in northern Mississippi during 2000 and 2001 using plant populations of 605 to 3068 plants/acre (1495-7581 plants/ha). Values are means \pm SE. Some error bars are small and covered by symbols. (a) 'Aspen': $\mathrm{y}=14.3+0.011 \mathrm{x}-0.000003 \mathrm{x}^{2}, P_{L}=0.0288, P_{O}=$ 0.0199; 'Howden Biggie': $\mathrm{y}=19.2-0.003 \mathrm{x}, P_{L}=0.008$; (b) 'Aspen': $\mathbf{y}=1379+2.08 x-0.0005 x^{2}, P_{L}=0.0041$, $P_{Q}=0.0056$; 'Howden Biggie': $y=1757-0.222 \mathrm{x}, P_{L}=$ 0.0972 . $\left(1.0\right.$ ton $/$ acre $=2.24 \mathrm{Mg} \cdot \mathrm{ha}^{-1}, 1.0$ acre $=0.405$ ha).

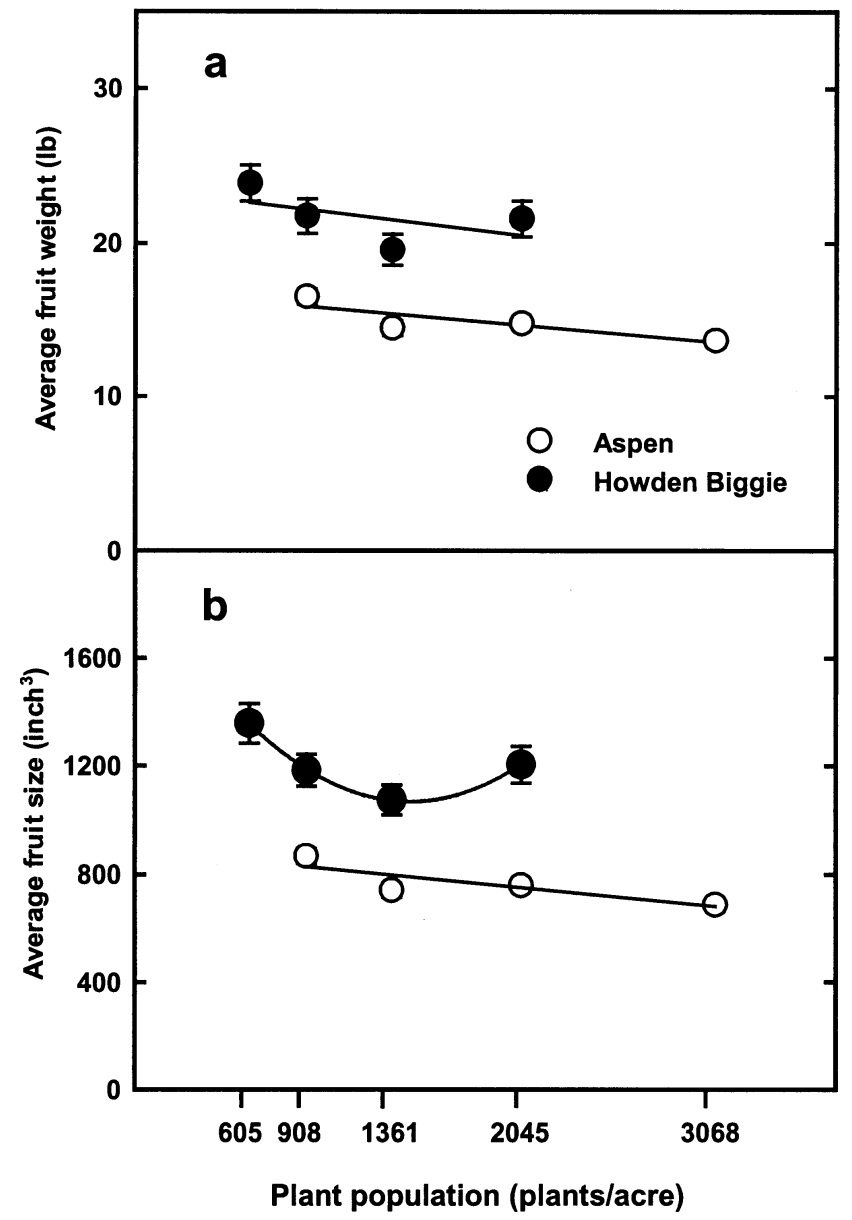

Fig. 3. Fruit size of pumpkin cultivars Aspen and Howden Biggie grown in northern Mississippi during 2000 and 2001 using plant populations of 605 to 3068 plants/acre (1495-7581 plants/ha). Values are means \pm SE. Some error bars are small and covered by symbols. (a) 'Aspen': $y=16.3$ - 0.001x, $P_{L}=0.0002$; 'Howden Biggie': $\mathrm{y}=22.8-0.002 \mathrm{x}$, $P_{L}=0.0309$; (b) 'Aspen': $\mathbf{y}=880-0.065 x, P_{L}=0.0003$; 'Howden Biggie': $\mathrm{y}=1753-0.981 \mathrm{x}+0.0003 \mathrm{x}^{2}, P_{L}=$ $0.0126, P_{Q}=0.0271$. $\left(1.0 \mathrm{lb}=0.45 \mathrm{~kg}, 1.0 \mathrm{inch}^{3}=16.39\right.$ $\mathrm{cm}^{3}, 1.0$ acre $=0.405$ ha $)$. row spacing constant at $8 \mathrm{ft}$. In one of their studies, between-row spacing was 6 or $12 \mathrm{ft}(1.8-3.6 \mathrm{~m})$. Reiners and Riggs also used moderate to high plant populations in their studies (1874 to 7495 and 1210 to 3626 plants/acre) whereas we used low to moderate populations in our experiments (605-3068 plants/acre). Our results are also not consistent with most other research with vine crops, where increasing plant population slightly increases yield and significantly increases number of fruit per acre (Wien, 1997).

Plant population significantly affected fruit weight and size (Fig. 3). As plant population increased, weight and size decreased slightly but significantly in a linear relationship for 'Aspen' (lb/ fruit and $\mathrm{inch}^{3} /$ fruit) and 'Howden
Biggie' (lb/fruit). Linear and quadratic terms, however, were significant for 'Howden Biggie' (inch ${ }^{3}$ /fruit), with minimum fruit size for the quadratic relationship occurring at about 1361 plants/acre. These results are consistent with other reports about the effect of plant population on fruit size and weight of vine crops, where increasing plant population generally results in decreasing fruit weight and size. For example, Edelstein and Nerson (2002) reported number of fruit per acre increased $\sim 100 \%$ while average fruit weight decreased $\sim 40 \%$ as plant population of watermelon increased 8 fold from 2024 to 16,188 plants/acre (5000-40,000 plants/ha).

Plant population greatly affected pumpkin yield components associated with plant productivity (Fig. 4). As plant population increased, number and weight of fruit per plant decreased sharply in a quadratic relationship for 'Aspen' (lb/plant and fruit/plant) and 'Howden Biggie' (lb/plant). Only the linear trend, however, was significant for 'Howden Biggie' (fruit/plant). Plant productivity was least at the highest plant populations. At the highest plant population for 'Aspen', 3068 plants/acre, each plant produced one marketable pumpkin. At the highest plant population for 'Howden Biggie', 2045 plants/acre, only $60 \%$ of the plants produced one marketable pumpkin. These results are consistent with other reports about the effect of plant population on plant productivity of vine crops. Reiners and Riggs 


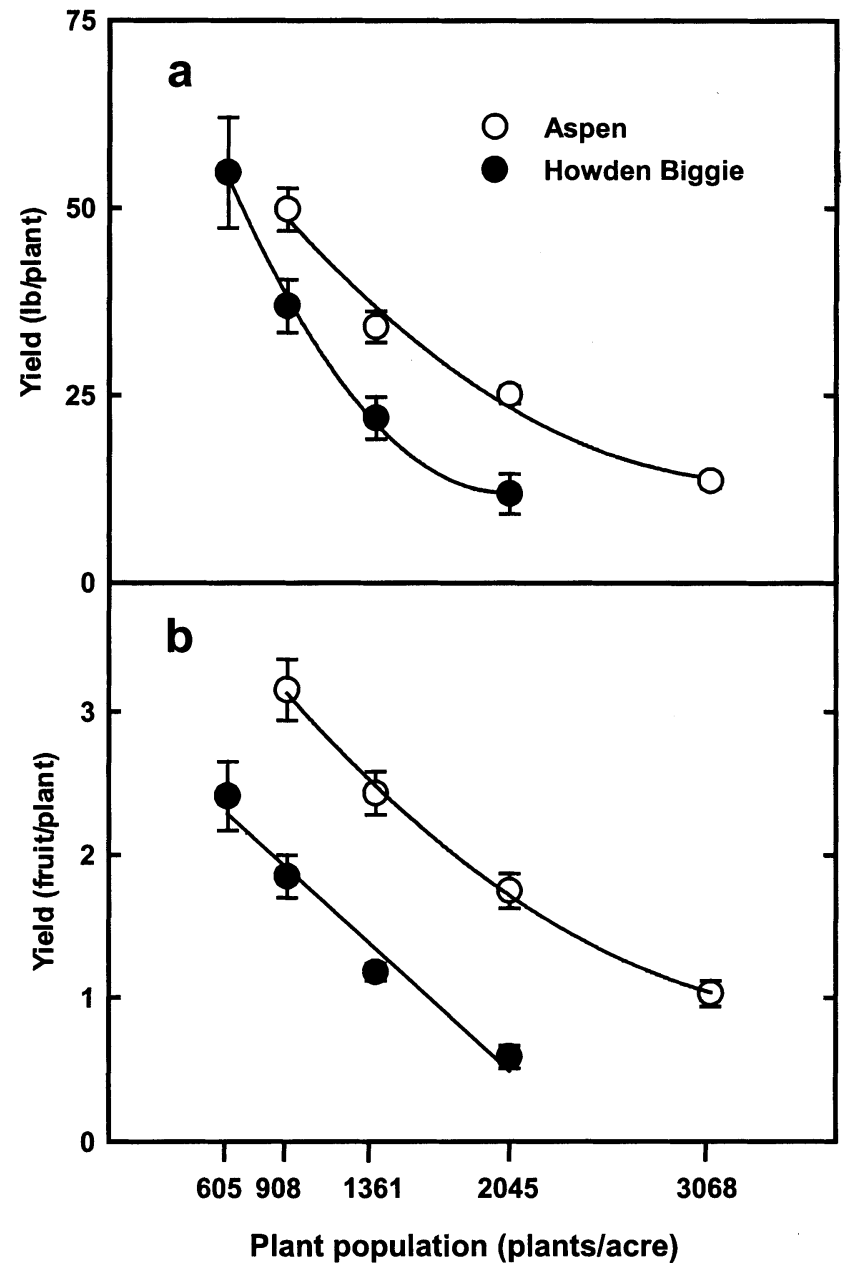

Fig. 4. Plant productivity of pumpkin cultivars Aspen and Howden Biggie grown in northern Mississippi during 2000 and 2001 using plant populations of 605 to 3068 plants/acre (1495-7581 plants/ha). Values are means \pm SE. Some error bars are small and covered by symbols. (a) 'Aspen': $\mathrm{y}=80-0.040 \mathrm{x}+0.000006 \mathrm{x}^{2}$, $P_{L}<0.0001, P_{Q}=0.0034$; 'Howden Biggie': $\mathbf{y}=97.8-0.085 \mathrm{x}+0.00002 \mathrm{x}^{2}$, $P_{L}=0.0002, P_{Q}=0.0074$; (b) 'Aspen': $\mathrm{y}=4.74-0.002 \mathrm{x}+0.0000003 \mathrm{x}^{2}, P_{L}=$ $0.0002, P_{Q}=0.0245$; 'Howden Biggie': $\mathrm{y}=3.04-0.001 \mathrm{x}, P_{L}<0.0001$. (1.0 lb $=0.45 \mathrm{~kg}, 1.0$ acre $=0.405 \mathrm{ha}$ ).
(1999) pointed out that plants that do not produce marketable fruit do not contribute to yield and essentially act as weeds, competing with fruited plants for light, water, and other resources.

Plant population did not appear to affect the relative distribution of fruit weight across selected weight categories (Table 2).

\section{Conclusions}

Low to intermediate plant populations were more productive than high populations for commercial pumpkin production under our growing conditions and with the 8-ft between-row spacing used in our experiments. Our results indicate that intermediate plant populations appear optimum for semi-vining cultivars such as 'Aspen', and recommendations should be centered on about 2045 plants/acre. Published recommendations from Kentucky appear sound, advocating plant populations within the range of 1360 to 2720 plants/acre (Table 1). For vining cultivars, such as 'Howden Biggie', our results indicate that lower plant populations appear optimum, and recommendations could be as low as 605 plants/acre. Published recommendations from Kentucky and Georgia, along with those published in Vegetable Crop Guidelines for the Southeastern U.S. (Sanders et al., 2004), advocate plant populations for vining cultivars within the range of approximately 725 to 1465 plants/acre (Table 1). Our results indicate that producers of vining cultivars could use plant populations from the lowest values of these recommendations

Table 2. Relative distribution of weight of pumplins grown at four plant populations in northern Mississippi during 2000 and 2001 . Values are percentages of total number of pumplins harvested per spacing treatment and may not total to exactly $100 \%$ due to rounding.

\begin{tabular}{|c|c|c|c|c|c|c|c|}
\hline & & \multicolumn{6}{|c|}{ Fruit wt [lb (kg)] } \\
\hline \multicolumn{2}{|c|}{ Plant population } & \multirow{2}{*}{$\begin{array}{c}<10 \\
(<4.5)\end{array}$} & \multirow{2}{*}{$\begin{array}{c}10-15 \\
(4.6-6.8)\end{array}$} & \multirow{2}{*}{$\begin{array}{c}15-20 \\
(6.8-9.1)\end{array}$} & \multirow{2}{*}{$\begin{array}{c}20-25 \\
(9.1-11.4)\end{array}$} & \multirow{2}{*}{$\begin{array}{c}25-30 \\
(11.4-13.6)\end{array}$} & \multirow{2}{*}{$\begin{array}{r}>30 \\
(>13.6)\end{array}$} \\
\hline Plants/acre & (Plants/ha) & & & & & & \\
\hline \multicolumn{8}{|c|}{ Aspen } \\
\hline 908 & $(2244)$ & 10 & 36 & 29 & 12 & 9 & 3 \\
\hline 1361 & $(3363)$ & 23 & 39 & 20 & 10 & 7 & 2 \\
\hline 2045 & $(5053)$ & 19 & 36 & 29 & 12 & 3 & 1 \\
\hline 3068 & $(7581)$ & 27 & 38 & 24 & 8 & 2 & 1 \\
\hline \multicolumn{8}{|c|}{ Howden Biggie } \\
\hline 605 & $(1495)$ & 8 & 13 & 18 & 19 & 17 & 24 \\
\hline 908 & $(2244)$ & 9 & 20 & 24 & 13 & 9 & 24 \\
\hline 1361 & $(3363)$ & 15 & 25 & 19 & 19 & 10 & 12 \\
\hline 2045 & $(5053)$ & 13 & 17 & 21 & 11 & 15 & 24 \\
\hline
\end{tabular}


or use even lower values. In doing so, producers should expect slightly higher yields, slightly larger fruit, and much greater plant productivity than producers selecting plant populations in the middle or upper portion of each range. These conclusions for vining cultivars, however, are based on our results with 'Howden Biggie'. This cultivar produces larger pumpkins than most other vining cultivars grown for the wholesale market and our results may vary with vining cultivars that produce smaller pumpkins. These recommendations are also for pumpkins grown in the humid southeastern United States that achieve excellent plant stands and receive recommended rates of fertilizer, irrigation, and pest control chemicals.

\section{Literature cited}

Daniello, F.J. 1996. Seedless watermelon. Texas commercial vegetable production guide. Texas A\&M Univ., College Station.

Dickerson, G.W. 2000. Commercial pumpkin production for New Mexico. Coop. Ext. Serv., College of Agr. and Home Econ. Guide H-231. I Jan. 2004. <http:/ /www. cahe.nmsu.edu/pubs/_h/h-231.pdf>.

Edelstein, M. and H. Nerson. 2002 . Genotype and plant density affect watermelon grown for seed consumption. HortScience 37:981-983.

Gaskell, M. and R. Smith. 1997. Pumpkin production in California. Univ. of Calif. Div. Agr. and Natural Resources. Publ. 7222. 1 Jan. 2004. <http://anrcatalog.ucdavis. edu/pdf/7222.pdf>.

Hochmuth, G.J., D.N. Maynard, C.S. Vavrina, W.M. Stall, T.A. Kucharek, S.E. Webb, T.G. Taylor, and S.A. Smith. 2001. Cucurbit production in Florida. Univ. of Florida Ext., Inst. of Food and Agr. Sci. HS725. 1 Jan. 2004. <http://edis.ifas.ufl. edu/CV123>.

Jones, T., B. Rowell, J. Strang, R. Bessin, and B. Nesmith. 1998. Kentucky pumpkin integrated pest management. IPM-12. 1 Jan. 2004. <http://www.uky.edu/Agriculture/IPM/manuals/ipml2pum.pdf>.

Kelley, W.T. and D.B. Langston, Jr. (eds.). 2001. Commercial production and management of pumpkins and gourds. Coop. Ext. Serv., Univ. of Georgia College of Agr. and Environ. Sci. Bul. 1180. 1 Jan. 2004. <http:www.ces.uga.edu/pubcd/B1180. htm\#Variety\%20Selection>.
Kemble, J.M., E.J.Sikora, G.W. Zehnder, and E. Bauske. 1997. Guide to commercial pumpkin and winter squash production. Alabama Ext. Publ. ANR-1041. 1 Jan. 2004. <www.aces.edu/pubs/docs/A/ ANR-1041/>.

Kultur, F., H.C. Harrison, and J.E. Staub. 2001. Spacing and genotype affect fruit sugar concentration, yield, and fruit size of muskmelon. HortScience 36:274-278.

Motsenbocker, C.E. and R.A. Arancibia. 2002. In-row spacing influences triploid watermelon yield and crop value. HortTechnology 12:437-440.

NeSmith, D.S. 1993. Plant spacing influences watermelon yield and yield components. HortScience 28:885-887.

Reiners, S. and D.I.M. Riggs. 1997. Plant spacing and variety affect pumpkin yield and fruit size, but supplemental nitrogen does not. HortScience 32:1037-1039.

Reiners, S. and D.I.M. Riggs. 1999. Plant population affects yield and fruit size of pumpkin. HortScience 34:1076-1078.

Rupp Seeds Inc. 2002.2003 Vegetable catalog. Rupp Seeds Inc., Wauseon, Ohio.

Sanders, D.C., J.D. Cure, and J.R. Schultheis. 1999. Yield response of watermelon to planting density, planting pattern, and polyethylene mulch. HortScience 34:1221-1223.

Sanders, D.C. (ed.), J.M. Kemble, E.J. Sikora, M.G. Patterson, R.L. Hassell, G. Miller, T. Keinath, J.K. Norsworthy, P. Smith, G.E. Boyhan, W.T. Kelley, D.B. Langston, A.S. Culpepper, A.S. Sparks, K.E. Cushman, D.H. Nagel, R.G. Snyder, D. Ingram, M.R. Williams, B.O. Layton, J.D. Byrd, M.W. Shankle, R.B. Batts, N.G. Creamer, J.M. Davis, W.R. Jester, D.W. Monks, J.R. Schultheis, G.T. Roberson, K.A. Sorensen, J.F. Walgenbach, D.B. Orr, C.W. Averre, M.A. Cubeta, G.J. Holmes, F.J. Louws, D.F. Ritchie, C.R. Crozier, G.D. Hoyt, R.S. Mylavaraped, and H.J. Savoy. 2004. Vegetable crop guidelines for the southeastern U.S. 2004-2005 Vance Publ. Corp., Lincolnshire, Ill., in cooperation with the N.C. Veg. Growers Assn., Raleigh, N.C.

Wien, H.C. 1997. The cucurbits: $\mathrm{Cu}^{-}$ cumber, melon, squash and pumpkin, p. 345-386. In: H.C. Wien (ed.). The physiology of vegetable crops. CABI Publ., New York. 